\title{
Factors Swaying Inspiration of Employees Performance in the Insurance Companies of Bangladesh: A Comparative Analysis Between Demographic Forces and Components of Organizational Commitment
}

\author{
Serena Aktar \\ Department of Business Administration, Northern University, Dhaka, Bangladesh \\ *Correspondence: Serena Aktar, serene7868@gmail.com
}

\begin{abstract}
The purpose of this study is to identify and examine the most inspirational factor of employees' performance in the perception of employees in the insurance companies of Bangladesh.

This empirical study has been conducted through an explanatory survey design. A survey with a structured questionnaire has been conducted for collecting primary data. A convenient random sampling technique was used to collect primary data for examining the relationship between the dependent and independent variables. It means the relationship between the three components of organizational commitment and inspiration of employees' performance; demographic factors and inspiration of employees' performance in the insurance companies of Bangladesh. A total number of 400 structured questionnaires were distributed and received back with properly filled 378 questionnaires that were statistically used for analysis. The statistical software SPSS (IBM 26) has been used for input and processing raw data into hypothetical final results. Descriptive statistics, binary correlation, multiple regression analysis, and lastly One-Way-ANOVA have been used step by step to test the hypothetical research results.
\end{abstract}

The results of this study indicated that a strong positive relationship exists between the educational ability \& experience of respondents from demographic factors and inspiration of employees' performance; continuance commitment of the respondents from components of organizational commitment and inspiration of employees' performance in insurance companies of Bangladesh. It is suggested in this research that the organization should pay attention to continuance committed employees having a high level of education and experience.

Keywords: Demographic factors, Components of organizational commitment, Employees performance, Insurance companies

\section{ARTICLE INFORMATION}

Author(s): Serena Aktar

Received: 02 Apr, 2021; Accepted: 07 May, 2021; Published: 24 Aug, 2021; e-ISSN: 2347-4696;

Paper Id: BMN-IJBMR-2021-33;

Citation: doi.org/10.37391/IJBMR.090307

Webpage-link:

https://ijbmr.forexjournal.co.in/archive/volume-9/ijbmr-090307.html

\section{INTRODUCTION}

In this forceful age of globalization, achieving and keeping organizational performance nationally and internationally are depended on various factors. Among all factors, employees are the most dynamic and responsible factors for attaining and keeping a good position within the industry boundaries. So, firms ought to notice the uncommon resources and capabilities of the employees that help to produce distinctive competency by offering distinctive and innovative products. Workers' perception regarding performance has been considered in this study with some key areas such as resources of achieving the company monetary performance, worker outcomes, achieving the additional market share, and keeping a good position within the industry boundaries. In this research, the researcher has tried to compare the most responsible factors between the demographic factors and the components of organizational commitment to bring employees' performance that has been conceptualized by reviewing some of the previous studies done separately on the demographic factors and the components of organizational commitments. Some researchers examined the link between the amount of worker commitment and intention to perform works higher of the staff whereas some researchers conjointly thought of employees' performance supported demographic variables [1-5]. The research concepts regarding the three components of organizational commitment such as affective components, continuance component, and normative component have been conceptualized from the studies by Allen and Meyer [6]; Polyglot outlined these three elements in numerous ways; however, ideas of all research's performance measure is similar. These three components or the basic elements of commitment are associated with the definitions of structure commitment that are found in the literature [7]. A study by Cohen [8] defined that affective commitment had been desired because organizations reach their goals and a sense of pride being a part of that organization. Meyer and Allen [9] mentioned in their study that people have an affective or emotional commitment to stay in the organization. They defined the normative commitment as staying in a particular organization as a result of they got to and finally people with strong continuance commitment to stay in a particular organization as a result of they have to. Continuance commitment is defied by Meyer, et al. [10] because continuance commitment of an individual's awareness is the 
price of going away from the organization. A worker with continuance commitment finds it troublesome to give up one's organization because of the concern of the unknown 'opportunity cost' of going away from the organization or having few or no alternatives. Normative commitment to the organization develops a set of pressures that people feel throughout their early socialization from family \& culture and through their socialization as newcomers to the organization [11]. So, the organizations need to rethink about the performance of the business turned in the performance of their staff that has been mentioned by some previous researchers $[12,13]$. Akintayo [14] and Tumwesigye [15] discovered that organizational performance depends on employees' commitment to get and preserve competitive advantage and win superior performance. Committed workers' performance measures extremely intended to contribute their time and energy to extend structure goals [16].

After reviewing a good number of works of literature, the researcher identified a gap to guide the study of this area. The hopeful research issues and gaps lead the researcher in formulating the objectives of identifying and comparing the sources of inspiration for employees' performance that might be recognized as the most influential or stirring factor swaying inspiration of employees' performance in the insurance companies in Bangladesh.

\section{THEORETICAL BACKGROUND}

In this study, the researcher reviewed and organized previous studies under two factors such as demographic factors and components of organizational commitments that have an impact on employees' performance. The demographic factors have considered some specific issues such as gender, age, academic ability, marital status, and experience that might have influenced employees' performance in this study. A few studies have found some findings on the impact of demographic factors and employees' performance. The studies by Schmidt, [17]; Shultz and Adam, [18] are shown that age, gender, work expertise, and academic ability have a positive influence on employees' performance. Smedley and Whitten [19] identified the positive impact getting on work performance. Darwin [20], knows young employees are unit additional economical in technology-based over the older employees. Azim, et al. [21] showed that in terms of gender, the degree of job satisfaction of workers' dissent. Yutaka and Ohzono [22] discovered that males had higher levels of labor values than females. Many empirical studies are conducted to look at the connection between demographic factors (e.g., age, gender, marital status, and education level, and job tenure) and structure commitment. Demographic factors were vital predictors of structure commitment, except gender, that wasn't a major predictor of organizational commitment. In another study, Chughtai and Zafar [23] investigated the impact of demographic factors on structure commitment and located that demographic factors weren't vital predictors of structure commitment. In this study, it has been assumed the following hypothesis:
$H_{1}$ : Demographic factors are the most influential in swaying inspiration for employees' performance in the insurance companies of Bangladesh.

In this study, the researchers reviewed the relationship between the components of employees' commitment and employees' performance. Irefin and Mechanic [24] showed a relationship between worker commitment and intent to remain or leave the organization and it was known that there would be a contradictory relationship between employees' commitment and their turnover wherever a suggestion has been provided that the management ought to rent employees WHO are doubtless to become connected to the organization; management ought to produce the clear and realistic job and structure previews. Dost and Ahmed [25] proved that organizational performance is often increased by involving workers in decisions that ultimately increased the commitment of the employees. Ali, et al., [26] found that there is a positive relationship between company social responsibility and worker commitment moreover as between worker commitment and their performance which also shown in the researches by McGregor [27]; Likert [28]; Argyris [29]; and Schneider, et al., [30]. Dessler [31]; Kristof, et al. [32] mentioned that there is a positive relationship between the workers' attitudes towards the organization and their job performance. Al Ahmadi [33] showed that employees' commitment could be a basic part to perform their job higher. The human resource system will facilitate the event or organizational competencies agitating employees' commitment.

Lambert, et al., examined the extent of employees' commitment and their performance. The impact of employees' commitment on structure performance because of the employees' commitment has become a significant part of the structure performance as shown in the research by Nabukeera, et al. [34]. It is stated that the human's area unit committed to their tasks can cause their better performance in the researches by Weiner [35]; Chapman and Galston [36]; Dent [37], MacIntyre [38] Aka and Abu (2016) discovered that there is a positive relationship between worker commitment and achieving a bigger market share, pursuance of international recognition, and worker retention. Khan, et al. [39] investigated the impact of the parts of worker commitment i.e., affective commitment, continuance commitment, and normative commitment on the employees' job performance and located a positive relationship between them. Therefore, it is assumed that the following hypothesis:

$\mathrm{H}_{2}$ : The components of organizational commitment are the most influential in swaying inspiration for employees' performance in the insurance companies of Bangladesh. 


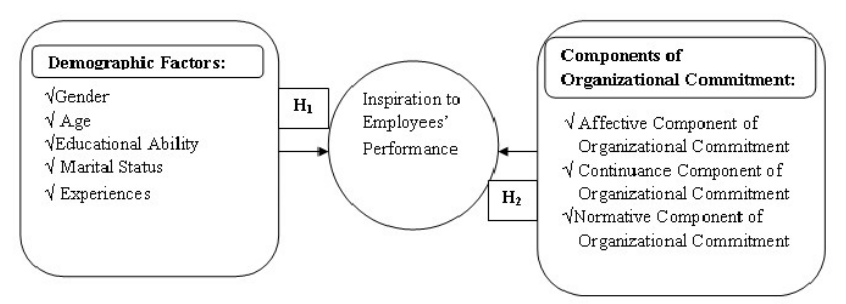

Figure 1: Sources of Employees’ Performance.

\section{METHODOLOGY}

Insurance Companies transfer the risk of the individual or the business enterprise. The economic development of the countries depends on the growth of those countries' development of the insurance industries. So, the economy and insurance are interdependent upon each other. Presently 76 insurance companies (45 general insurance companies and 31 life insurance companies) are operating in Bangladesh along with two public insurance companies such as Sadharan Bima Corporation and Jibon Bima Corporation' ${ }^{1}$. Among 76 insurance companies, 11 companies such as, Sonali Life Insurance Company Limited, Asia Pacific Gen Insurance Limited, Bangladesh National Insurance Company Limited, MetLife Bangladesh, Eastland Insurance Company Limited, Express Insurance Limited, Federal Insurance Company Limited, Fareast Islami Life Insurance Company Limited, Jamuna Life Insurance Limited, Meghna Insurance Company Limited, Alpha Islami Life Insurance Limited, have been selected as conveniently. Out of total 400 questionnaires that have been distributed to several kinds of employees of earlier selected 11 companies, 378 questionnaires were returned back with well-filled up which were statistically usable. Only 22 questionnaires were rejected due to minor problems in filling up the questionnaire. This study has been developed based on a literature review and expected the desired findings as exploratory research. Both primary and secondary categories of data were required objectively. An extensive survey was required to collect the primary data from the employees of identifying and examining the most influential factors of inspiring employees' performance in the insurance companies. According to research objectives of this study, the researcher designs the questionnaire which was divided into three segments such as demographic-related questions, questions related to the level of commitment of the respondents, and in the last part, questions regarded to determine the level of performance in perspective to the perception of the employees. Five-Points-Likert Scale has been used to identify the level of commitment and the level of performance of the employees but in the part of demographic aspect, options like close-ended questions were used for respondents to respond easily. Wellknown statistical software SPSS (IBM 26) was used to code and analyze the collected primary data. Some necessary tools were inserted through the software to proven the hypothetical results. Reliability analysis, descriptive statistics (frequency distribution), correlation analysis, regression analysis, and

\footnotetext{
${ }^{1}$ https://biabd.org/economic-contribution-of-theinsurance-industry/
}

lastly hypothesis testing have been used for fulfilling the desired level of outcome for this study.

\section{ANALYSIS AND DISCUSSION}

\subsection{Reliability Analysis}

Reliability is the overall consistency of a measure. A measure is considered as high reliability if it produces the same results under consistent conditions. One of the most popular tools to measure the reliability statistics in recent studies is Cronbach's alpha [40]. Cronbach's (alpha) is used in estimating the reliability of the users' data in a study. It can be viewed as the expected correlation of two tests that measure the same construct. Alpha coefficient ranged from 0 to 1 and may be used to describe the reliability of factors extracted from dichotomous (that is, questions with two possible answers) and/or multi-point formatted questionnaires or scales (i.e., rating scale: 1 = poor, 5 = excellent). Again, Nunnally [41] identified that a value of 0.70 to be an acceptable reliability coefficient.

\begin{tabular}{|c|c|}
\hline Cronbach's Alpha & $\begin{array}{c}\text { Cronbach's Alpha Based on } \\
\text { Standardized Items }\end{array}$ \\
\hline 0.606 & 0.493 \\
\hline
\end{tabular}

Table 1: Reliability Test (Source: Field Survey on November, 2019).

Table 1 shows the internal reliability of this study. The internal reliability of the instrument was checked using Cronbach's alpha. The result of Cronbach alpha was 0.606 which is close to the standard value presented by Nunnally [41], i.e. 0.70 . Therefore, this is understood that the instrument used in this study had strong internal reliability and it could be used with confidence for the application of further statistical analysis and interpretation.

\subsection{Descriptive Statistics}

Descriptive statistics were generated from the questionnaire to get an idea about respondents under the study. From the responses for the accessibility of analysis percentage of the responses is given in table 2 .

Table 2 shows that 221 respondents are male and 157 are female. The mean score for respondents' gender is 1.42 and the standard deviation is 0.493 (Standard Error of Mean is 0.025). Table 2 presents the age distribution of the respondents. Among 378 employees; 156 are between 18-25 years old, 103 are between $26-35$ years old, 80 are between $36-45$ years old and lastly 39 are above 46 years old. The mean score for respondents' age is 2.01 and the standard deviation is 1.020 (Standard Error of Mean is 0.052).

Table 2 also shows that out of 378 respondents, 312 are graduates, 57 are post-graduate degree holders and only 9 respondents are below H.S.C. The mean score for respondents' educational qualification is 3.13 and the standard deviation is 0.399 (Standard Error of Mean is 0.021). 


\begin{tabular}{|c|c|c|c|c|c|c|}
\hline $\begin{array}{l}\text { Demographic } \\
\text { Variables }\end{array}$ & $\begin{array}{lll}\text { Categories } & \text { of } & \text { Each } \\
\text { Variables } & & \end{array}$ & Frequency & Percent & Mean & $\begin{array}{l}\text { Std. Error of } \\
\text { Mean }\end{array}$ & $\begin{array}{l}\text { Std. } \\
\text { Deviation }\end{array}$ \\
\hline \multirow[t]{3}{*}{ Gender } & Male & 221 & 58.5 & \multirow[t]{3}{*}{1.42} & \multirow{3}{*}{0.025} & \multirow[t]{3}{*}{0.493} \\
\hline & Female & 157 & 41.5 & & & \\
\hline & Total & 378 & 100.0 & & & \\
\hline \multirow[t]{5}{*}{ Age } & $18-25$ & 156 & 41.3 & \multirow[t]{5}{*}{2.01} & \multirow[t]{5}{*}{0.052} & \multirow[t]{5}{*}{1.020} \\
\hline & $26-35$ & 103 & 27.2 & & & \\
\hline & $36-45$ & 80 & 21.2 & & & \\
\hline & 46-above & 39 & 10.3 & & & \\
\hline & Total & 378 & 100.0 & & & \\
\hline \multirow[t]{4}{*}{ Education } & HSC & 9 & 2.4 & \multirow[t]{4}{*}{3.13} & \multirow[t]{4}{*}{0.021} & \multirow[t]{4}{*}{0.399} \\
\hline & Graduation & 312 & 82.5 & & & \\
\hline & Post-Graduation & 57 & 15.1 & & & \\
\hline & Total & 378 & 100.0 & & & \\
\hline \multirow[t]{3}{*}{ Marital Status } & Married & 149 & 39.4 & \multirow[t]{3}{*}{1.61} & \multirow[t]{3}{*}{0.025} & \multirow[t]{3}{*}{0.489} \\
\hline & Unmarried & 229 & 60.6 & & & \\
\hline & Total & 378 & 100.0 & & & \\
\hline \multirow[t]{6}{*}{ Experience } & $1-5$ & 135 & 35.7 & \multirow[t]{6}{*}{2.30} & \multirow[t]{6}{*}{0.060} & \multirow[t]{6}{*}{1.174} \\
\hline & $6-10$ & 72 & 19.0 & & & \\
\hline & $11-15$ & 98 & 25.9 & & & \\
\hline & $16-20$ & 67 & 17.7 & & & \\
\hline & 20 and above & 6 & 1.6 & & & \\
\hline & Total & 378 & 100.0 & & & \\
\hline
\end{tabular}

Table 2: Demographic Statistics of the Respondents for Insurance Companies (Source: Field Survey on November, 2019).

Table 2 also shows that most of the respondents are married i.e. 149 respondents are married out of 378 respondents and 229 are unmarried. The mean score for respondents' marital status is 1.61 and the standard deviation is 0.489 (Standard Error of Mean is 0.025). Out of 378 respondents, 135 have been working for 1 to 5 years, 72 have been working for 6 to 10 years, 98 have been working for 11 to 15 years, 67 have been working for 16 to 20 years and only 6 having working experiences for 20 years and above. The mean score for respondents' job experience is 2.30 and the standard deviation is 1.174 (Standard Error of Mean is 0.060).

\subsection{Correlation Analysis}

Correlation analysis is a method of statistical evaluation used to study the strength of a relationship between two, numerically measured, continuous variables. A correlation table is shown in table 3.

\begin{tabular}{|l|l|l|l|l|l|}
\hline \multicolumn{2}{|c|}{ Demographic Forces and Performance } & \multicolumn{2}{c|}{ Components of Commitment and Performance } \\
\hline Variables & Sig. (2-tailed) & $\begin{array}{l}\text { Pearson } \\
\text { Correlation }\end{array}$ & Variables & $\begin{array}{l}\text { Sig. (2-tailed) } \\
\text { Correlation }\end{array}$ \\
\hline Gender & 0.001 & $-.174^{* *}$ & $\begin{array}{l}\text { Affective } \\
\text { Commitment }\end{array}$ & 0.001 & -.021 \\
Age & 0.120 & 0.080 & $\begin{array}{l}\text { Continuance } \\
\text { Commitment }\end{array}$ & 0.683 & $0.301^{* *}$ \\
\cline { 1 - 2 } $\begin{array}{l}\text { Educational } \\
\text { Ability }\end{array}$ & 0.079 & 0.090 & $\begin{array}{l}\text { Normative } \\
\text { Commitment }\end{array}$ & 0.000 & $-.281^{* *}$ \\
\hline Marital Status & 0.000 & $-.278^{* *}$ & $* *$ Correlation is significant at the 0.01 level (2-tailed). \\
\hline Experience & 0.001 & $0.169^{* *}$ & & \\
\hline
\end{tabular}

Table 3: Correlation Analysis between Demographic Forces and Performance; Components of Commitments and Performance (Source: Field Survey on November, 2019).
Table 3 shows the relationship (correlation) between demographic forces and perception about employees' performance. In the case of insurance companies: there are strong negative correlation between gender and perception about employees' performance $(\mathrm{r}=-.174 * *, \mathrm{p}=0.001)$; between marital status and perception about employees' performance $\left(\mathrm{r}=-.278^{* *}, \mathrm{p}=0.000\right)$. On the other side, it is found that there are strong significant positive correlation between age and perception about employees' performance ( $\mathrm{r}$ $=0.080, \mathrm{p}=0.120)$; between education and perception about employees' performance $(\mathrm{r}=0.090, \mathrm{p}=0.079)$; between experience and perception about employees' performance $(\mathrm{r}=$ $\left.0.169^{* *}, \mathrm{p}=0.001\right)$. Among all demographic forces: the value of ( $\mathrm{r}$ ) experience is the highest which implies there is a strong significant positive correlation between the experience of employees and their perception about employees' performance. 
Table 3 also shows the relationship (correlation) between components of organizational commitments and their perception on employees' performance. In the case of insurance companies, there is negative correlation between affective commitment and perception about employees' performance $(\mathrm{r}=-.021, \mathrm{p}=0.001)$; between normative commitment and perception about employees' performance $(\mathrm{r}$ $=-.281^{*}, \mathrm{p}=0.000$ ). On the other side, it is found that there is a strong significant positive correlation between continuance commitment and perception about employees' performance $(\mathrm{r}$ $\left.=0.301^{* *}, \mathrm{p}=0.683\right)$. Among all three components of

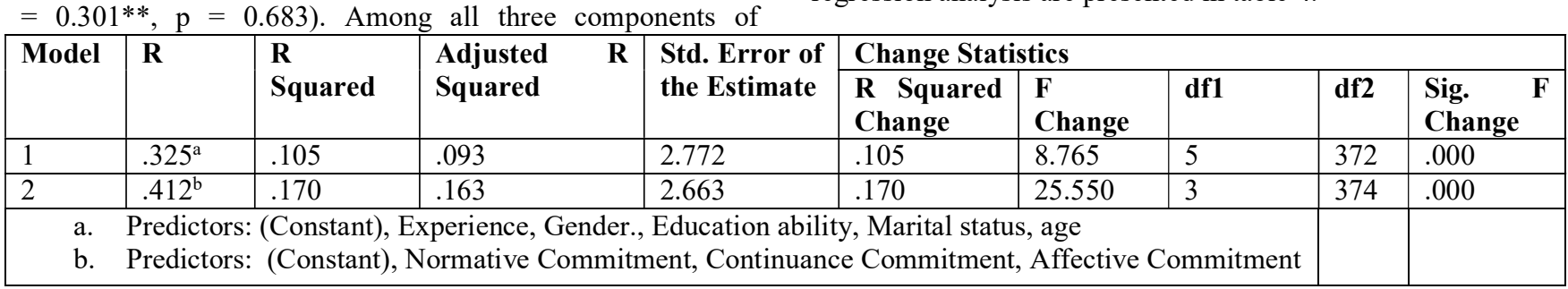

Table 4: Model Summary (Source: Field Survey on November, 2019).

Table 4 demonstrates the calculation (model-1) that $\mathrm{R}$ is 0.325 which means the used model is moderately fitted. The value of $\mathrm{R}^{2}=0.105$ implies demographic forces are $10.5 \%$ correlated with employees' performance and no change has been shown between $\mathrm{R}$ Squared and $\mathrm{R}$ Squared change. The value of adjusted $R$ Squared is high (0.093) which is near to the value of R squared.

Table 4 demonstrates the calculation (model-2) that $\mathrm{R}$ is 0.412 which means the used model is moderately fitted. The value of $\mathrm{R}^{2}=0.170$ which implies the commitment of employees is $17.0 \%$ correlated with employees' performance and there is no change between R Squared and R Squared change. The value of adjusted $\mathrm{R}$ Squared is high (0.163) which is near to the value of $R$ squared.

Coefficient analysis shows the relationship between the dependent variable and each independent variable.

Model-1:

$Y=\alpha+\beta_{1} X_{1}+\beta_{2} X_{2}+\beta_{3} X_{3}+\beta_{4} X_{4}+\beta_{5} X_{5}+\ldots \ldots \ldots \ldots \ldots+\beta n X n$

$Y=\alpha+\beta_{1} X_{1}+\beta_{2} X_{2}+\beta_{3} X_{3}+€$

$\mathrm{Y}=12.346+(.565) \mathrm{X}_{1}+(.324) \mathrm{X}_{2}+0.929 \mathrm{X}_{3}+(1.601) \mathrm{X}_{4}+0.166 \mathrm{X}_{5}+$ $€$

Table 5 showed that the constant value is 12.346, the coefficient of gender, $\beta_{1}$ is -.565 so it implies that the employees' performance can be changed by -.565 units with a $1 \%$ change in gender of the respondents. The coefficient of the age, $\beta_{2}$ is -.324 so it implies that employees' performance can commitment; the (r) value of continuance commitment is the highest which implies there is a significant positive correlation between continuance commitment of the employees and their perception about employees' performance.

\subsection{Regression Analysis}

In order to prove the impact of each independent variable on the dependent variable and to check the hypothesis developed, linear regression analysis was applied. Results of linear regression analysis are presented in table 4.

\begin{tabular}{|l|l|l|l|l|l|l|}
\hline \multirow{2}{*}{ Model } & \multicolumn{2}{l|}{ Unstandardized Coefficients } & $\begin{array}{l}\text { Standardized } \\
\text { Coefficients }\end{array}$ & t & \multirow{2}{*}{ Sig. } \\
\cline { 3 - 8 } \multicolumn{2}{|l|}{} & B & Std. Error & Beta & & \\
\hline \multirow{3}{*}{1} & (Constant) & 12.346 & 1.318 & & 9.365 & .000 \\
\cline { 2 - 8 } & Gender & -.565 & .313 & -.096 & -1.808 & .071 \\
\cline { 2 - 8 } & Age & -.324 & .180 & -.113 & -1.794 & .074 \\
\cline { 2 - 8 } & Education ability & .929 & .396 & .127 & 2.345 & .020 \\
\hline
\end{tabular}




\begin{tabular}{|l|l|l|l|l|l|l|}
\hline \multirow{2}{*}{2} & -1.601 & .375 & -.269 & -4.268 & .000 \\
\cline { 2 - 7 } & Earital status & .166 & .166 & .067 & 1.003 & .316 \\
\hline \multirow{5}{*}{2} & Constant) & 9.423 & 1.739 & & 5.420 & .000 \\
\cline { 2 - 7 } & Affective Commitment & .054 & .036 & .074 & 1.488 & .138 \\
\cline { 2 - 7 } & Continuance Commitment & .252 & .041 & .293 & 6.214 & .000 \\
\cline { 2 - 7 } & Normative Commitment & -.171 & .029 & -.297 & -5.968 & .000 \\
\hline \multicolumn{2}{|l|}{ Dependent Variable: Employees' Performance } \\
\hline
\end{tabular}

Table 5: Coefficients ${ }^{\mathrm{a}}$ (Source: Field Survey on November, 2019).

\subsection{Hypotheses Testing}

\begin{tabular}{|c|c|c|c|c|c|c|}
\hline Variables & & Sum of Squares & df & Mean Square & $\mathbf{F}$ & Sig. \\
\hline \multirow{3}{*}{$\begin{array}{l}\text { Demographic Forces } \\
\left(\mathrm{H}_{1}\right)\end{array}$} & Regression & 336.785 & 5 & 67.357 & 8.765 & $.000^{\mathrm{a}}$ \\
\hline & Residual & 2858.823 & 372 & 7.685 & & \\
\hline & Total & 3195.608 & 377 & & & \\
\hline \multirow{3}{*}{$\begin{array}{l}\text { Gender } \\
\left(\mathrm{H}_{1 \mathrm{a}}\right)\end{array}$} & Between Groups & 16.773 & 11 & 1.525 & 7.439 & .000 \\
\hline & Within Groups & 75.018 & 366 & .205 & & \\
\hline & Total & 91.791 & 377 & & & \\
\hline \multirow{3}{*}{$\begin{array}{l}\text { Age } \\
\left(\mathrm{H}_{1 \mathrm{~b}}\right)\end{array}$} & Between Groups & 40.664 & 11 & 3.697 & 3.851 & .000 \\
\hline & Within Groups & 351.325 & 366 & .960 & & \\
\hline & Total & 391.989 & 377 & & & \\
\hline \multirow{3}{*}{$\begin{array}{l}\text { Education ability } \\
\left(\mathrm{H}_{1 \mathrm{c}}\right)\end{array}$} & Between Groups & 3.638 & 11 & .331 & 2.151 & .016 \\
\hline & Within Groups & 56.267 & 366 & .154 & & \\
\hline & Total & 59.905 & 377 & & & \\
\hline \multirow{3}{*}{$\begin{array}{l}\text { Marital status } \\
\left(\mathrm{H}_{1 \mathrm{~d}}\right)\end{array}$} & Between Groups & 14.025 & 11 & 1.275 & 6.120 & .000 \\
\hline & Within Groups & 76.243 & 366 & .208 & & \\
\hline & Total & 90.267 & 377 & & & \\
\hline \multirow{3}{*}{$\begin{array}{l}\text { Experience } \\
\left(\mathrm{H}_{1 \mathrm{e}}\right)\end{array}$} & Between Groups & 77.492 & 11 & 7.045 & 5.827 & .000 \\
\hline & Within Groups & 442.521 & 366 & 1.209 & & \\
\hline & Total & 520.013 & 377 & & & \\
\hline \multirow{3}{*}{$\begin{array}{l}\text { Components of } \\
\text { Commitment } \\
\left(\mathrm{H}_{2}\right)\end{array}$} & Regression & 543.538 & 3 & 181.179 & 25.550 & $.000^{\mathrm{b}}$ \\
\hline & Residual & 2652.071 & 374 & 7.091 & & \\
\hline & Total & 3195.608 & 377 & & & \\
\hline \multirow{3}{*}{$\begin{array}{l}\text { Affective } \\
\text { Commitment } \\
\left(\mathrm{H}_{2 \mathrm{a}}\right)\end{array}$} & Between Groups & 880.475 & 11 & 80.043 & 5.703 & .000 \\
\hline & Within Groups & 5137.292 & 366 & 14.036 & & \\
\hline & Total & 6017.767 & 377 & & & \\
\hline \multirow{3}{*}{$\begin{array}{l}\text { Continuance } \\
\text { Commitment } \\
\left(\mathrm{H}_{2 \mathrm{~b}}\right)\end{array}$} & Between Groups & 874.123 & 11 & 79.466 & 8.426 & .000 \\
\hline & Within Groups & 3451.645 & 366 & 9.431 & & \\
\hline & Total & 4325.767 & 377 & & & \\
\hline \multirow{3}{*}{$\begin{array}{l}\text { Normative } \\
\text { Commitment } \\
\left(\mathrm{H}_{2 \mathrm{c}}\right)\end{array}$} & Between Groups & 3023.216 & 11 & 274.838 & 15.089 & .000 \\
\hline & Within Groups & 6666.392 & 366 & 18.214 & & \\
\hline & Total & 9689.608 & 377 & & & \\
\hline
\end{tabular}

Table 6: Analysis of Variances (Source: Field Survey on November, 2019).

In the case of demographic forces $\left(\mathrm{H}_{1}\right)$, the value of regression is 336.785 , the value of residual is 2858.823 , and the value of $\mathrm{F}$ - test is 8.765 . The P-value of demographic forces is $0.000(\mathrm{p}$ $<0.01 / 0.05$ ) which implies that the null hypothesis is rejected and the alternative hypothesis is accepted.

In the case of sub-hypotheses of hypothesis $\mathrm{H}_{1}$ from the table6 , it showed that in the case of gender forces of the respondents, the value of between groups is 16.773 , the value
It is required that the hypothesis testing to test a claim about a parameter in a population, should use the data measured in a sample. Table 6 shows the results of testing the hypotheses.

of within groups is 75.018, and the value of F- test is 7.439. The P-value of gender $\left(\mathrm{H}_{1 \mathrm{a}}\right)$ forces is $0.000(\mathrm{p}<0.01 / 0.05)$ which implies that the null hypothesis is rejected and the alternative hypothesis is accepted; in the case of age forces of the respondents, the value of between groups is 40.664 , the value of within groups is 351.325 and the value of $\mathrm{F}$ - test is 3.851. The $\mathrm{P}$-value of age $\left(\mathrm{H}_{1 b}\right)$ is $0.000(\mathrm{p}<0.01 / 0.05)$ which implies that the null hypothesis is rejected and the alternative hypothesis is accepted; in the case of education ability among 
demographic forces of the respondents, the value of between groups is 3.638 , the value of within groups is 56.267 and the value of $\mathrm{F}$ - test is 2.151 . The $\mathrm{P}$-value of education ability $\left(\mathrm{H}_{1 \mathrm{c}}\right)$ is $0.016(\mathrm{p}<0.05)$ which implies that the null hypothesis is rejected and the alternative hypothesis is accepted; in the case of the marital status of demographic forces of the respondents, the value of between groups is 14.025 , the value of within groups is 76.243 and the value of F- test is 6.120. The P-value of marital status $\left(\mathrm{H}_{1 \mathrm{~d}}\right)$ is $0.000(\mathrm{p}<0.01 / 0.05)$ which implies that the null hypothesis is rejected and the alternative hypothesis is accepted; in the case of the experience of the respondents, the value of between groups is 77.492, the value of within groups is 442.521 and the value of F- test is 5.827 . The $\mathrm{P}$-value of experience $\left(\mathrm{H}_{1 \mathrm{e}}\right)$ is $0.000(\mathrm{p}<0.01 / 0.05)$ which implies that the null hypothesis is rejected and the alternative hypothesis is accepted.

Again, table 6 shows the results of components of organizational commitment $\left(\mathrm{H}_{2}\right)$ of the respondents, the value of regression is 543.538, the value of residual is 2652.071 and value of $\mathrm{F}$ - test is 25.550. The $\mathrm{P}$-value of components of organizational commitment is 0.000 ( $\mathrm{p}<0.01 / 0.05)$ which implies that the null hypothesis is rejected and the alternative hypothesis is accepted.

Independently, table 6 shows that the affective commitment of the respondents, the value of between groups is 880.475 , the value of within groups is 5137.292, and the value of F- test is 5.703. The P-value of affective commitment $\left(\mathrm{H}_{2 \mathrm{a}}\right)$ is $0.000(\mathrm{p}$ $<0.01 / 0.05)$ which implies that the null hypothesis is rejected and the alternative hypothesis is accepted; in the case of continuance commitment of the respondents, the value of between groups is 874.123 , the value of within groups is 3451.645 and the value of $\mathrm{F}$ - test is 8.426. The P-value of continuance commitment $\left(\mathrm{H}_{2 b}\right)$ is $0.000(\mathrm{p}<0.01 / 0.05)$ which implies that the null hypothesis is rejected and the alternative hypothesis is accepted; in the case of normative commitment, the value of between groups is 3023.216 , the value of within groups is 6666.392 and the value of $\mathrm{F}$ - test is 15.089 . The $\mathrm{P}$ value of normative commitment $\left(\mathrm{H}_{2 \mathrm{c}}\right)$ is $0.000(\mathrm{p}<0.01 / 0.05)$ which implies that the null hypothesis is rejected and the alternative hypothesis is accepted.

\begin{tabular}{|c|c|c|}
\hline Hypotheses & Description & Results \\
\hline $\mathrm{H}_{1}$ & $\begin{array}{l}\text { Demographic factors are the most influential in swaying inspiration for employees' } \\
\text { performance in the insurance companies of Bangladesh. }\end{array}$ & Accepted \\
\hline $\mathrm{H}_{1 \mathrm{a}}$ & $\begin{array}{l}\text { There exists a positive influence of gender forces on swaying inspiration to performance } \\
\text { of employees in insurance companies of Bangladesh. }\end{array}$ & Accepted \\
\hline $\mathrm{H}_{1 \mathrm{~b}}$ & $\begin{array}{l}\text { There exists a positive influence of age forces on swaying inspiration to performance of } \\
\text { employees in insurance companies of Bangladesh. }\end{array}$ & Accepted \\
\hline $\mathrm{H}_{1 \mathrm{c}}$ & $\begin{array}{l}\text { There exists a positive influence of educational ability on swaying inspiration to } \\
\text { performance of employees in insurance companies of Bangladesh. }\end{array}$ & Accepted \\
\hline $\mathrm{H}_{1 \mathrm{~d}}$ & $\begin{array}{l}\text { There exists a positive influence of marital status forces on swaying inspiration to } \\
\text { performance of employees in insurance companies of Bangladesh. }\end{array}$ & Accepted \\
\hline $\mathrm{H}_{1 \mathrm{e}}$ & $\begin{array}{l}\text { There exists a positive influence of experience forces on swaying inspiration to } \\
\text { performance of employees in insurance companies of Bangladesh. }\end{array}$ & Accepted \\
\hline $\mathrm{H}_{2}$ & $\begin{array}{l}\text { The components of organizational commitment are the most influential in swaying } \\
\text { inspiration for employees' performance in the insurance companies of Bangladesh. }\end{array}$ & Accepted \\
\hline $\mathrm{H}_{2 \mathrm{a}}$ & $\begin{array}{l}\text { There is a positive influence of affective components of organizational commitment on } \\
\text { swaying inspiration to performance of employees in insurance companies of Bangladesh. }\end{array}$ & Accepted \\
\hline $\mathrm{H}_{2 \mathrm{~b}}$ & $\begin{array}{l}\text { There is a positive influence of continuance components of organizational commitment } \\
\text { on swaying inspiration to performance of employees in insurance companies of } \\
\text { Bangladesh. }\end{array}$ & Accepted \\
\hline $\mathrm{H}_{2 \mathrm{c}}$ & $\begin{array}{l}\text { There is a positive influence of normative components of organizational commitment on } \\
\text { swaying inspiration to performance of employees in insurance companies of Bangladesh. }\end{array}$ & Accepted \\
\hline
\end{tabular}

Table 7: Summary Results of the Hypotheses Testing (Source: Table 6).

Table 7 shows the result summary of the hypotheses, it has been found that two hypotheses have been accepted which imply there is a positive influence of demographic forces (i.e. gender, age, educational ability, marital status, and experiences) and components of organizational commitment (i.e. Affective, continuance and normative) on swaying inspiration to performance of employees in insurance companies of Bangladesh.

\section{CONCLUSION}

In the case of insurance companies, there is a huge variety in the official working and activates. The employees of Insurance companies in Bangladesh are enthusiastic, creative and they look for scopes. But the culture of Bangladesh is different from the developed countries in view of insurance of their life and properties. Here people are reluctant to pay a claim against risks. So, it is necessary for employees of the insurance companies to work hard. The main focus of this study is to identify sources of employees' performance who are working for insurance companies in Bangladesh. The researcher identified two sources i.e. demographic characteristics of the 
employees which itself works as a force of performance, and components of commitment toward the organization of the employees which is also a force of employee performance. Both factors have been developed based on the literature in various fields.

From the result, it is compelled to conclude that the concept of organizational commitment in our country is yet to build up. In this research, employees of the insurance companies focused on the continuance commitment components of staying in job and perform best on their jobs. It is also showed that the performance of the employees depends on demographic factors such as educational ability and experience on their job. Two hypotheses have been proven by testing through the OneWay-ANOVA test which revealed that the P-value of $\mathrm{H}_{1}$ is 0.000 and the $\mathrm{P}$-value of $\mathrm{H}_{2}$ is 0.000 . So, two hypotheses have been proven scientifically and given results that demographic characteristics, as well as an organizational commitment, are accountable as the sources of employees' performance in the insurance companies of Bangladesh. This result has been matched with some previous studies i.e. Owens P. [42], who found in his studies that committed employees lead to higher organizational performance and a very low level of employee shift from the organization. Arthur J. [43] concluded that organizational performance has been enhanced by a higher level of employee commitment. Martin and Bennett [44] revealed that highly educated people were more committed to working. The quality of the employees had a high impact on the success of organizations [45]. Education and work experience are the two forms of human capital individuals are most likely to acquire during their careers [46-48].

\section{SUGGESTION FOR MANAGERS AND FUTURE RESEARCHERS}

The results of the study indicated that the educational ability and experience of respondents from demographic factors are the most stimulus of employees' performance; continuance commitment of the respondents from components of organizational commitment has the most inspiration of boosting employees' performance in the insurance companies of Bangladesh. It is suggested that the organizations should pay attention to continuance committed employees having a high level of education and experience.

In this study, only four specific performance dimensions have been considered as representing of employees' performance i.e., core task performance, citizenship behavior, creativity and counterproductive work behaviors. There are some other dimensions that can be focused on in future research such as workplace aggression, substance use, less tardiness, and less absenteeism in the workplace. It is identified that educational ability and experience of demographic forces and continuance component of organizational commitment have a positive influence on the employees' performance in the insurance companies of Bangladesh. So, the manager of the insurance companies can focus on three factors such as educational ability, experience, and continuance commitment to their hiring, promoting, and retaining policy which is only considerable factors for managing employees' performance of the insurance companies. In this research, the researcher only focused insurance sector which may bring different results to other sectors such as the bank, pharmaceuticals, readymade garments sector, and so on. So, it also could be a future direction for further studies.

\section{REFERENCES}

[1] Amarasena, T.S.M, Ajward, A.R. Haque, A.K.M.A. (2015). The effects of demographic factors on job satisfaction of university faculty members in Sri Lanka. International Journal of Academic Research and Reflection, 3(4), 89-106.

[2] Akova, O., Cetin, G. Cifci, I. (2015). The relation between demographic factors and the turnover intention in pre-opening hotel businesses. Procedia - Social and Behavioural Sciences, 207, 377-384.

[3] Akpa, V.O, Asikhia, O.U. (2016). Effects of demographic factors on employees' intention to leave in selected private universities in Southwest, Nigeria. The international Journal of Business \& Management, 4(10), 322-330.

[4] Brown, E. A., Arendtb, S. W., Bosselmanc, R. H. (2014). Hospitality management graduates' perceptions of career factor importance and career factor experience. International Journal of Hospitality Management, 27, 58-67.

[5] Weberova, D., Hitka, M. Lizbetinova, L. (2017). Age and gender motivating differences of slovak workers. International Review of Management and Marketing, 7(1), 505-513.

[6] Allen, N. J., Meyer, J. P., (1990). The measurement and antecedents of affective, continuance and normative commitment to the organization. Journal of Occupational Psychology, 63 (1), 1-18.

[7] Turner, B. A. Chelladurai, P. (2005). Organizational and occupational commitment, intention to leave and perceived performance of intercollegiate coaches. Journal of Sport Management, 19 (2), 193-211.

[8] Cohen, A., (2003). Multiple Commitments in the Workplace. Mahwah. NJ: Lawrence Erlbaum.

[9] Meyer, J. P. Allen, N. J. (1997). Commitment in the workplace: Theory, Research, And Application. Sage Publications, Inc.

[10] Meyer, J. P., Allen, N. J. Smith, C. A. (1993). Commitment to organizations and occupations: extension and test of a threecomponent conceptualization. Journal of Applied Psychology, 78(4), 538-551.

[11] Meyer, J. P., Stanley D. J., Herscovitch, L. Topolnytsky, L. (2002). Affective, continuance, and normative commitment to the organization: A meta-analysis of antecedents, correlates, and consequences. Journal of Vocational Behavior, 61(1), 20-52.

[12] Ajila, C. Awonusi, A. (2004). Influence of rewards on workers performance in an organization. Journal of Social Science, 8(1), 7-12.

[13] Richard, P., Devinney, T., Yip, G Johnson, G. (2009). Measuring organizational performance: towards methodological best practice. Journal of Management.

[14] Akintayo D.I. (2010). Work-Family Role Conflict and Organizational Commitment Among Industrial Workers in Nigeria. Journal of Psychology and Counselling, 2(1), 1-8.

[15] Tumwesigye, G. (2010). The relationship between perceived organizational support and turnover intentions in a developing country: the mediating role of organizational commitment. African Journal of Business Management, 4(6), 942-952. 
[16] Hunjra, A.I., Ali, M.A., Chani, M.I, Khan, H. Rehman, K. (2010). Employee voice and intent to leave: an empirical evidence of pakistani banking sector. African Journal of Business Management, 4(14), 3056-3061.

[17] Schmidt, R. (1990). The Role of consciousness in second language learning. Applied Linguistics, 11, 129-158.

[18] Shultz, K. S. Adam, G. A. (2007). Aging and work in the 21st century. New Jersey: Routledge Publisher.

[19] Smedley, K. Whitten, H. (2006). Age Matters, employing, motivating and managing older employees. United Kingdom: Gower Publisher.

[20] Darwin, R. J. (2014). Age diversity and its impact on employee performance in Singapore. International Journal of Research and Development in Technology and Management Science, 211(5), 79-98.

[21] Azim, M. T., Haque, M. M. Chowdhury, A. (2013). Gender, marital status and job satisfaction: an empirical study. International Review of Management and Business Research, 2(2), 488-498.

[22] Yutaka, U. Ohzono, Y. (2013). Differences in work values by gender, marital status and generation: an analysis of data collected from working persons survey 2010. International Journal of Human Resource Studies, 3, 2.

[23] Chughtai, A. A., Zafar, S. (2006). Antecedents and consequences of organizational commitment among pa-kistani university teachers. Applied HRM Research, 11(1), 39-64.

[24] Irefin, P. Mechanic, M. A. (2014). Effect of employee commitment on organizational performance in coca cola Nigeria limited Maiduguri, Borno state. Journal of Humanities and Social Science, 19(3), 33-41.

[25] Dost, M. K. B. Ahmed, D. Z. (2011). Impact of employee commitment on organizational performance. Arabian Journal of Business and Management Review, 1(3), 87-98.

[26] Ali, I., Rehman, K., Ali S.I., Yousaf, J. Zia, M. (2010). Corporate social responsibility influences, employee commitment and organizational performance. African Journal of Business Management, 4(12), 2796-2801.

[27] McGregor, D. (1960). The Human Side of Enterprise. New York: McGraw-Hill.

[28] Likert, R. L. (1961). The Human Organization. New York: McGraw-Hill.

[29] Argyris, C. (1964). Integrating the individual and the organization. New York: Wiley.

[30] Schneider, B., Hanges, P. J., Smith, D. B., Salvaggio, A. N. (2003). Which comes first: Employee attitudes or organizational financial and market performance? Journal of Applied Psychology, 88, 836-851.

[31] Dessler, G. (2011). Human Resource management. PrenticeHall, USA.

[32] Kristof-Brown, A., Zimmerman, R. Johnson, E.C. (2005). Consequences of individualse ${ }^{\text {e }}$ fit at work: A meta-analysis of person-job, person-organization, person-group, and personsupervisor fit. Personnel Psychology, 58(2), 281-342.
[33] Al Ahmadi, H. (2009). Factors affecting performance of hospital nurses in Riyadh Region, Saudi Arabia. International Journal Health Care Quality Assurance, 22(1), 40-54.

[34] Nabukeera, M., Ali B. Raja, N.B. (2015). Performance evaluation of public service institutions (CQS) Framework. World Journal of Social Science, 2(1), 1-25.

[35] Weiner, N.O. (1993). The harmony of the soul: mental health and moral virtue reconsidered. Albany, NY: State University of New York Press.

[36] Chapman, J.W., Galston, W.A. (1992). Virtue. New York: New York University Press.

[37] Dent, N. (1984). The Moral Psychology of the Virtues. New York: Cambridge University Press.

[38] MacIntyre, A. (1984). After Virtue: A Study in Moral Theory. Notre Dame, IN: University of Notre Dame Press

[39] Khan, H., Razi, A., Ali, S.A. Asghar, A. (2013). A study on relationship between organizational job commitment, and its determinants among CSRS and managerial level employees of pakistan (Telecommunication Sector). Interdisciplinary Journal Contemporary Research, 3(11), 269-284.

[40] Cronbach, L. J. (1970). Essentials of psychological testing (3rd ed.). New York: Harper \& Row.

[41] Nunnally J C. (1978). Psychometric theory. New York: McGraw Hill, 701.

[42] Owens, P. L. (2006). One more reason not to cut your training budget: The relationship between training and organizational outcomes. Public Personnel Management, 35(2), 163-171.

[43] Arthur, J. B. (1994). Effects of human resource systems on manufacturing performance and turnover. The Academy of Manufacturing Performance, 37(3), 670-687.

[44] Martin, C.L. Bennett, N. (1996). The role of justice judgments in explaining the relationship between job satisfaction and organizational commitment. Group and Organization Management, 21(1), 84-104.

[45] Sepehri, M., Batman, O., Kıngır, S., Arpaci, Ö. (2014). A survey review in conflict management strategies: The case study for selected hotels in Turkey. Journal of Management and Marketing Research, 16, 1-10.

[46] Myers, M.B., Griffeth, D.A., Daugherty, P.J. Lusch, R.F. (2004). Maximizing the human capital equation in logistics: education, experience, and skills. Journal of Business Logistics, 25, 211232.

[47] Singer, M.S. Bruhns, C. (1991). Relative effect of applicant works experience and academic qualification on selection interview decisions: A study of between-sample generalizability. Journal of Applied Psychology, 76, 550-559.

[48] Strober, M.H. (1990). Human capital theory: implications for HR managers. Industrial Relations, 29, 214-239.

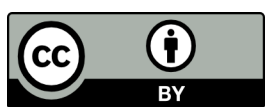

Commons (http://creativecommons.org/licenses/by/4.0/).
(C) 2021 by the Serena Aktar. Submitted for possible open access publication under the terms and conditions of the Creative $\begin{array}{llll}\text { Attribution } & (\mathrm{CC} & \mathrm{BY}) & \text { license }\end{array}$ 